\title{
Alimentação, agronegócio e pandemia: um debate para o tempo presente
}

\author{
Food, agribusiness and pandemic: a debate for the present time
}

Alimentación, agroindustria y pandemia: un debate para la actualidad

PANDEMIA E AGRONEGÓCIO: DOENÇAS INFECCIOSAS, CAPITALISMO E CIÊNCIAS. Wallace R. São Paulo: Editora Elefante; 2020. 608 p. ISBN: 978-65-87235-05-9.

doi: 10.1590/0102-311X00291620

O livro de Rob Wallace chega ao Brasil em meio à pandemia da COVID-19 e da crise ambiental enfrentada principalmente na Região Amazônica 1 e no Pantanal brasileiro. Os dois fenômenos têm em comum fortes laços com o agronegócio. A edição estadunidense intitulada Big Farms Make Flu: Dispaches on Influenza, Agribusiness and the Nature of Science foi publicada em 2016, já a edição brasileira 2, lançada no segundo semestre de 2020, conta com o acréscimo de dois textos sobre a pandemia da COVID-19; os demais textos foram escritos ao longo das duas últimas décadas. De acordo com autor, os artigos reunidos no livro foram pensados para leitores distintos: alguns para o público em geral, outros originados de palestras direcionadas para leitores especializados. Além do prefácio e da introdução, a obra conta com oito partes que englobam diferentes campos do conhecimento, um debate interdisciplinar que dialoga com a Biologia Evolutiva, Ecologia, Sociologia e Geografia Econômica.

Logo no início do livro, o autor apresenta argumentações que nortearão todo o trabalho: segundo ele, as grandes corporações do setor de alimentos, as chamas Big Foods, estabelecem uma aliança estratégica com o influenza, ou seja, são as principais responsáveis pelo vírus e, ao mesmo tempo, lucram com ele. O autor destaca que o agronegócio tem transferido suas empresas para o Sul global, para otimizar seus lucros, já que a região tem custo baixo da mão de obra de trabalho e dos preços das terras. Ele exemplifica, de forma clara, as estratégias corporativas do setor. "...o Grupo CP, da Tailândia, hoje o quarto maior produtor de aves do mundo, opera indústrias avícolas na Turquia, na China, na Malásia, na Indonésia e nos Estados Unidos. Possui fazendas de ração na Índia, na China, na Indonésia e no Vietnã” (p. 61). Com a estratégia de distribuição de plantas industriais ao redor do mundo, o surto pandêmico iniciado em uma fábrica pode ser lucrativo para as demais plantas: "Quando ocorreu um surto de gripe aviária em uma fazenda operada pelo Grupo CP na província de Heilongjiang, o Japão proibiu a importação de aves da China. As fábricas da CP na Tailândia conseguiram aproveitar a brecha e aumentaram as exportações para o Japão" (p. 61). Em outras palavras, a empresa lucrou com um surto que ela mesmo criou.

À primeira vista, o livro de Wallace poderia provocar tensões relacionadas à elevada quantidade de informações sobre a dinâmica do sistema agroalimentar e a consequente produção de crises pandêmicas. Na sociedade contemporânea, segundo Fischler 3, vivenciamos um cenário de "gastroanomia". O autor ressalta que recebemos um amplo conjunto de informações sobre 
comida, essas "ideologias alimentares" são, na sua maior parte, contraditórias. Ou seja, a elevada quantidade de informação provoca, na maioria das pessoas, uma angústia de não saber o que comer nem qual orientação seguir. Os dados e teorias apresentados por Wallace, por um lado, são perturbadores, já que apresentam em detalhes a engrenagem do agronegócio mundial, por outro, é uma oportunidade de apresentar informações qualificadas para politizar a prática dos consumidores. Na visão de Portilho \& Barbosa 4, esse processo de "politização do consumo" seria uma forma de o consumidor participar de um campo de disputas sobre o que é, de que modo a sociedade a produz e consome.

Estaríamos em um caldeirão de patógenos? Para Wallace, há fortes evidências de que a pecuária e a avicultura intensiva estão na origem de muitas pandemias. A dispersão para outros países ocorre devido ao alcance geográfico da cadeia de commodities do setor, que se espalha por todos os continentes. $\mathrm{O}$ autor utiliza a categoria "doenças agrícolas" para se referir a doenças que atingem animais e plantações industrializadas e geneticamente modificadas. Nesse cenário, os benefícios de curto prazo para a eficiência produtiva e distributiva do agronegócio surgem apenas por meio de uma série de subsídios e de altos custos para as populações locais e para o meio ambiente de forma geral.

Como possibilidade de saída, são propostas abordagens alternativas de "agricultura de conservação". Essas abordagens sugerem menores custos de insumos mediante métodos de produção orgânicos e naturalmente renováveis. De certa forma, o livro propõe mudanças radicais no modelo de produção agrícola capitaneado pelo agronegócio, ao tratar a comida como fonte de nutrição, não como mercadoria. Nas palavras do autor, "Há uma ampla capacidade de produção de alimentos, mesmo com uma população crescente, se tratarmos a comida como fonte de nutrição ecologicamente integrada e não apenas como mercadoria" (p. 355). Tal cenário em que a solução da atual crise passa pela construção de uma sociabilidade que não mercantilize os bens da Natureza.
Uma das críticas possíveis ao trabalho de Wallace deve-se ao fato de o autor não deixar clara a definição de agronegócio. Em sua obra, o agronegócio aparece como um ator homogêneo, representado pelas Big Foods, as grandes corporações do setor alimentar. $\mathrm{O}$ agronegócio é um ator com múltiplas faces e distintos atores, ao longo da cadeia do sistema agroalimentar. O debate atual sobre agronegócio tem origem no conceito de agribusiness, proposto por Davis \& Goldberg 5; a definição incorpora todas as operações de produção e de distribuição de suprimentos agrícolas, do armazenamento, do processamento e da distribuição dos produtos agrícolas e de itens produzidos a partir deles.

Na última parte do livro, Wallace faz questão de não desvincular o surgimento da COVID-19 de outras pandemias que sugiram recentemente: a peste suína africana, os ebolas, a febre aftosa, a hepatite E, as variantes do influenza A, entre outras. Os surtos não seriam resultados de má sorte. De alguma forma, todos estariam ligados, direta e indiretamente, às transformações na produção ou no uso do solo associado à agricultura intensiva. Em suma: “...tanto a pecuária quanto a agricultura impulsiona o desmatamento e os empreendimentos que aumentaram a taxa e o alcance taxonômico do transbordamento de patógenos: dos animais selvagens para os da pecuária e, destes, para os trabalhadores do setor" (p. 527). Por meio do comércio global, as cepas desenvolvidas podem ser exportadas para todos os continentes.

Um dos aspectos centrais propostos na obra é a necessidade de repensar os custos do agronegócio, eles não estariam expressos nos relatórios contábeis das corporações multinacionais. " $O$ agronegócio emprega capital político para externalizar as consequências mais prejudiciais inerentes ao seu modelo de produção a consumidores, governos, produtores rurais, trabalhadores agrícolas, comunidades rurais..." (p. 534). Além dos prejuízos fiscais e materiais, observa-se a redução da diversidade ambiental, a poluição, as perdas na autonomia de agricultores locais.

Para finalizar, a obra defende, claramente, que doenças infecciosas não dizem respeito ape- 
nas ao próprio vírus, mas também ao contexto do qual ele emerge. Com uma visão otimista, o autor destaca que devemos adotar muitas das práticas cotidianas de povos indígenas e dos pequenos agricultores. Ele utiliza uma expressão zapatista que diz "criarmos un mundo donde quepan muchos mundos". A única receita para enfrentar o futuro incerto seria a valorização de sistemas produtivos diversificados e sustentáveis.

Se, por um lado, o desmatamento e a expansão do agronegócio brasileiro avançam em direção à Amazônia, ao Pantanal e ao Cerrado, por outro, temos povos indígenas, comunidades remanescentes de quilombos, seringueiros, ribeirinhos, geraizeiros, ou seja, um conjunto amplo de povos que vivem em "terras tradicionalmente ocupadas" 6, grupos que expressam uma diversidade de formas de existência coletiva e de relações com os recursos da Natureza extremamente equilibrada.

\section{Daniel Coelho de Oliveira 1}

1 Universidade Estadual de Montes Claros, Montes Claros, Brasil.

daniel.oliveira@unimontes.br

\section{Informação adicional}

ORCID: Daniel Coelho de Oliveira (0000-00032565-6551).

1. Arruda D, Candido HG, Fonseca R. Amazon fires threaten Brazil's agribusiness. Science 2019; 365:1388.

2. Wallace R. Pandemia e agronegócio: doenças infecciosas, capitalismo e ciências. São Paulo: Editora Elefante; 2020.

3. Fischler C. El (h)omnívoro: el gusto, la cocina y el cuerpo. Barcelona: Editorial Anagrama; 1995.

4. Portilho F, Barbosa L. A adesão à "causa” rural e da agricultura familiar por consumidores e seus movimentos organizados. In: Marques FC, Conterato MA, Schneider S, organizadores. Construção de mercados e agricultura familiar: desafios para o desenvolvimento rural. Porto Alegre: Editora da UFRGS, 2016. p. 251-73.

5. Davis JH, Goldberg RA. A concept of agribusiness. Boston: Harvard University Graduate School of Business Administration; 1957.

6. Almeida AWB. Terras tradicionalmente ocupadas: processos de territorialização, movimentos sociais e uso comum. Revista Brasileira de Estudos Urbanos e Regionais 2004; 6:9-32. 